\title{
The Effect of Organizational Structure on Organizational Justice Perceptions of Employees
}

\author{
Mehtap Özşahin ${ }^{1 *}$, Senay Yürür ${ }^{2}$ \\ ${ }^{1}$ Assistant Professor, Yalova University \\ ${ }^{2}$ Full Professor, Yalova University
}

\begin{tabular}{l}
\hline \\
Keywords: \\
Organizational Justice, \\
Centralization, \\
Formalization, Distributive \\
Justice, Procedural Justice, \\
Interactional Justice \\
\hline Received \\
28 May 2018 \\
Received in revised form \\
22 October 2018 \\
Accepted \\
24 October 2018 \\
\hline
\end{tabular}

Correspondence:

mehtap.ozsahin@yalova.edu.tr

\section{Abstract}

The antecedents of perceived fairness of employees about their executives and organizations need to become evident because organizational justice results in both positive and negative changes in behaviours and attitudes of employees. Although, organizational justice refers to the employees' perceptions about organizational structure and practices, the studies systematically examining organizational factors as antecedents of organizational justice are very rare. In this context, this survey aiming to search the effects of structural factors in terms of centralization and formalization on organizational justice perception of employees is expected to contribute to literature. The survey is conducted on 356 employees of 15 SMEs operating in manufacturing and service industry in Marmara Region-Turkey. Data obtained from those 356 questionnaires were analysed through the AMOS statistical program. Confirmatory factor analysis (CFA) using AMOS 22.00 statistical programme is conducted to test construct validity and reliability. To test hypotheses, researchers employed structural equation modelling (SEM) with maximum likelihood estimation. Survey findings revealed a positive relationship between formalization level as a component of organizational structure and perceived organizational justice of employees, which is consistent with the previous studies in literature. The finding of this survey revealing a non-significant effect of centralization on procedural and distributive justice is inconsistent with the most of previous studies. However, two surveys conducted in Turkey about that issue had produced similar results strikingly. Thus, findings of a non-significant effect of centralization on procedural and distributive justice but a positive effect on interactional justice may have some Turkish culture-specific implications. 
Organizational justice, referring to the perceived fairness of employees in workplace (Folger \& Cropanzano, 1998), has been studied in organizational behavior literature in an outstanding manner (e.g., organizational citizenship behavior, Moorman, 1991; organizational commitment, McFarlin and Sweeney, 1992; job satisfaction, McFarlin and Sweeney, 1992; performance, Cohen-Charash and Spector, 2001; employee theft, Greenberg, 1990; counterproductive behaviors, Fox, Spector and Miles, 2001) because organizational justice results in both positive and negative changes in behaviors and attitudes of employees; therefore, the antecedents of perceived fairness of employees about their executives and organizations need to become evident. However, most of the studies examining that issue predominantly have focused on the consequences of organizational justice rather than the antecedents (Mayer, Nishii, Schneider, \& Goldstein, 2007; Yürür, 2015). Clarification of individual and organizational antecedents, shaping the employees' perceptions on organizational justice, will provide a substantial contribution to elaborate explanation of organizational justice. A few studies examining antecedents of organizational justice mostly have focused on individual factor. Moreover, in the studies conducted in Turkey, individual factors, specifically demographic characteristics of employees, have been examined as the antecedent of organizational justice (Yürür, 2015). Although, organizational justice refers to the employees' perceptions about organizational structure and practices, the studies systematically examining organizational factors as antecedents of organizational justice are very rare (Ambrose \& Schminke, 2003). Thus, surveys inquiring that how organizational context -in term of structural features and managerial attributions- shapes the fairness perception, are expected to contribute to literature.

In addition to macro level studies focusing on the effects of organizational structure on other organization related issues (e.g., customer orientation formation and implementation, Auh \& Menguc, 2007; R\&D investment decision process efficacy, Davis-Sramek, Germain, \& Krotov, 2015; innovation performance, Yang, Zhou, \& Zhang, 2015), some micro level surveys stating structural effects on employees' attitudes and behaviors have been familiar to literature for a long time (Ivancevich \& Donnelly, 1975; Lambert, Paoline, \& Hogan, 2006; Oldham \& Hackman, 1981). In this context, this survey aiming to search the effects of structural factors in terms of centralization and formalization on organizational justice perceptions of employees is expected to contribute to literature.

\section{Theoretical Background}

The argument of this research states that the organizational structure would shape the employees' perception on organizational justice, based on social exchange theory (Blau, 1964). This theory helps us to understand reciprocal relationships between employees and their organizations by explaining long term exchanges among social entities. In contrast to economic exchange theory, social exchange theory has focused on long-term socio-psychological exchanges in this reciprocal relation. According to social exchange theory, any act of one side will be responded by other side. In this exchange relation, an individual can be responded by other individuals (as like manager, co-worker) or an organization. Thus, individual's response to injustice will change according to source of injustice. In other words, it is argued that employees will differentiate manager-related injustice from organization-based injustice 
(Masterson, Lewis, Goldman, \& Taylor, 2000). While interactional justice perception, based on fairness of relationship between employee and his/her manager, will affect employee's relations to the manager; procedural justice perception will direct the employee's attitude and behaviors to the organization. Thus organizational structure can be considered as organization based social exchange factor that shapes the employees' justice perception.

As Schminke, Ambrose, and Cropanzano (2000) indicated, some organizations are perceived more fair because of some structural characteristics. For example, presence of rule to do works according to procedure, or presence and enforcement level of written rules and procedures determine organization's tendency toward justice or injustice in terms of structure. In this context, centralization and formalization will be handled as structural factors, and the effects of those factors on organizational justice perception will be examined.

\section{Organizational Structure and Organizational Justice Relationship}

Studies on organizational justice predominantly recognize three distinct forms of organizational justice: distributive, procedural, and interactional (Cropanzano, Prehar, \& Chen, 2002). Distributive justice refers to the employees' fairness perception about the distribution of outcomes (Greenberg, 1990), while procedural justice refers to the perceived fairness of the processes that lead to those outcomes (Leventhal, 1980). Interactional, the most recently recognized form of justice refers to the interpersonal treatment people receive as procedures are enacted, and is more related to the quality of the relationship between the supervisor and the subordinate (Bies \& Moag, 1986).

While it has been discussed whether organizational justice is best represented by two or three factors, Greenberg (1993) suggested a four-factor structure for organizational justice by repositioning interactional justice as two separate dimensions- interpersonal and informational. Four-factor view of justice was tested and justified empirically for the first time by Colquitt's survey in 2001. Informational justice was conceptualized as the fairness of explanations and information provided to the people who are influenced by distribution decisions, while interpersonal justice was defined as fairness of interpersonal treatment provided during the enactment of procedures and distributions of outcomes (Greenberg, 1993). However, factor analyses result of previous studies conducted in Turkey, which used Colquitt's (2001) FourFactor-Scale, revealed three-factor structure of organizational justice scale (e.g. Yürür \& Demir, 2011). Thus, three-factor structure of organizational justice has been used in this survey.

On the other hand, organizations, referring to social entities constituted to achieve specified objectives and operate in coordination with external environment, have been characterized by two dimensions-structural and contextual dimensions (Daft, 2015). Formalization level, specialization level and centralization level of organizations constitute a part of structural dimension. Centralization is defined as "inverse of the amount of delegation of decisionmaking authority throughout an organization and the extent of participation by organizational members in decision-making" (Jaworski \& Kohli, 1993, p. 56). The level of centralization is related to the hierarchical level in the organization at which decisions are made (Childs, 1973), thus the power of the decision making being placed at the top level of the organization means high level of centralization in that organization. In highly centralized organizations, decision- 
making power is concentrated at the upper levels, while in highly decentralized organizations, it is delegated to the lower levels, and employees have discretion in their activities.

In organizational behavior literature, it is indicated that delegation of decision making power to lower level increases the employees' fairness perception (Greenberg \& Baron, 2000; Tyler, 2000). Employees participating in decision making process feel that they have control over decisions, thereby perceive the decision making process as more fair (Thibaut \& Walker, 1978). When they have power to make decisions, they represent their interest in a better way which strengths the fairness perception of employees about process and outcomes (Thibaut \& Walker, 1978). Therefore, in highly centralized organizations, the perceived fairness is expected to be decreased. Previous surveys on that issue also support that argument indicating an inverse correlation between centralization and organizational justice (Andrews \& Kacmar, 2001; Schminke, Ambrose, \& Cropanzano, 2000; Schminke, Cropanzano, \& Rupp, 2002). Moreover, two studies conducted in Turkey about that issue revealed a negative effect of centralization on perceived fairness (Altıntaş, 2007; İçerli, 2009).

In the light of the theory and previous studies, the hypotheses are proposed as below:

$\mathbf{H}_{1 \mathbf{a}}$ : High level of centralization is negatively correlated to perceived procedural justice of employees

$\mathbf{H}_{1 \mathbf{b}}$ : High level of centralization is negatively correlated to perceived distributive justice of employees

$\mathbf{H}_{1 \mathbf{c}}$ : High level of centralization is negatively correlated to perceived interactional justice of employees

Jaworski and Kohli define organizational formalization as "the degree to which rules define roles, authority relations, communications, norms, sanctions, and procedures" (1993, p. 56). Formalization is viewed as the level to which an organization precisely describes/states rules and procedures on job related behaviors and activities in different situations (Hage \& Aiken, 1967). Those stated rules and procedures designate what will be done when and how by employees, it constrains decision making flexibility (Fredrickson, 1986), thereby prevents arbitrary decisions. In highly formalized, employees believe that everybody is treated equally in the same circumstances, because requirements for reward or sanctions are precisely defined. Therefore, when employees recognize that organization has a highly formalized structure, they consider that they are more fairly treated. In that kind of highly formalized organizations, everyone is subject to same rules and is treated equally under the same circumstances. In light of those arguments, it can be expected that high level of organizational formalization results in high level of perceived justice in organizations.

Parallel to this expectation, two surveys conducted in Turkey revealed a positive effect of formalization level on procedural justice (Altıntaş, 2007), distributive justice and interactional justice (İçerli, 2009). Although, in their previous study, Schminke et al. (2000) indicated a nonsignificant relation between formalization and procedural justice; subsequently Schminke et al. (2002) found out that formalization influenced procedural justice and distributive justice positively depending on the hierarchical level of employees. Paralles to Scminke et al. (2002), Andrews and Kacmar (2001) stated the positive effect of formalization on procedural justice. 
In the light of the theory and above arguments, the following hypotheses are proposed:

$\mathbf{H}_{\mathbf{2}}$ : High level of formalization is positively correlated to perceived procedural justice of employees

$\mathbf{H}_{2 \mathbf{b}}$ : High level of formalization is positively correlated to perceived distributive justice of employees

$\mathbf{H}_{2 \mathbf{c}}$ : High level of formalization is positively correlated to perceived interactional justice of employees

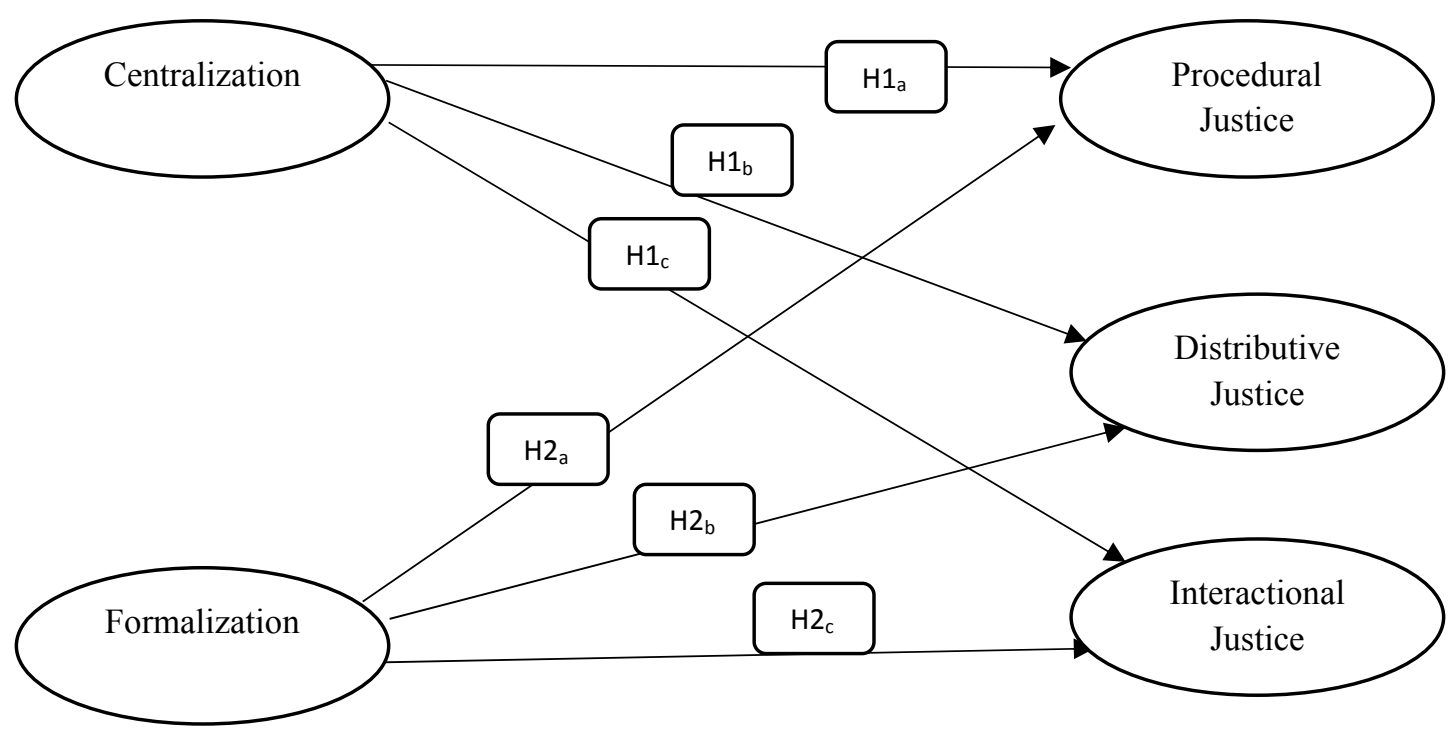

Figure 1. Research model

\section{Method}

A questionnaire survey method is used to collect the data for the purpose of this study. The survey has been conducted on 15 SMEs operating in manufacturing and service industry in Marmara Region-Turkey. Overall, 356 questionnaire forms were filled out by employees and managers of 15 SMEs thorough face-to-face survey administration. Data obtained from the questionnaires were analysed through the AMOS statistical program. To test hypotheses, the researcher employed structural equation modelling (SEM) with maximum likelihood estimation.

\section{Sample}

Of the 356 respondents, 280 were blue and white colour employees while 75 of them low and middle level managers. Moreover, $28 \%$ of respondents had primary school degree, $21 \%$ high school degree and $35 \%$ university degree. Female respondents constituted $47 \%$ percent of all respondents. More than half of respondents were between 28 years and 41 years old (13\% of respondents 17-27 years old; $61 \%$ were $28-41$ years old; $26 \%$ were 42 years old and elder). Data obtained from those 356 questionnaires were analysed through the AMOS statistical program. 


\section{Measures}

Scales used to measure constructs in this study had been translated into Turkish before and used at previous surveys conducted in Turkey by the researchers (organizational justice scale by Yürür and Demir (2011); formalization and centralization scale by Özşahin, 2005). The researcher benefited from the previous scales frequently used in literature to construct the measurement instruments of the questionnaire. In this regard, a multidimensional scale of organizational justice based on the measurement instrument of the best known study of Colquitt (2001) was used. The measurement instrument of organizational justice consists of 20 items based on three dimensions - procedural justice ( 7 items), distributive justice (4 items), and interactional justice ( 9 items). The measurement of formalization was adopted from the studies of Baum and Wally (2003), originally developed by Khandwalla (1977), which includes 3 items. Finally, to measure centralization, 5 items-scale adopted from the study of Jaworski and Kohli (1993), originally developed by Aiken and Hage (1968) was used. Participants were asked to assess their firms in terms of given items. Overall, 28 items measuring centralization, formalization and organizational justice were assessed with FivePoint-Likert Type scale with responses of $1=$ strongly disagree to $5=$ strongly agree.

\section{Measure Refinement and Validity}

Following the two-step approach recommended by Anderson and Gerbing (1988), the researcher firstly checked for validity of the measurement model through confirmatory factor analysis (CFA). In this step, the researcher tested for construct validity by testing construct unidimensionality, reliability and convergent validity and discriminant validity. Once the measurement model is validated, at second step, the researcher conducted path analysis to test research model incorporating hypotheses.

Confirmatory factor analysis (CFA) using AMOS 22.00 statistical programme was conducted to test construct validity and reliability. Garver and Mentzer (1999) strongly recommend CFA to test construct validity and reliability because it delivers a more rigorous and precise test of construct validity compared to more traditional techniques such as exploratory factor analysis (EFA). For assessing construct unidimensionality in CFA, 1) the overall measurement model fit; and 2) components of the measurement model fit should be provided (Steenkamp \& Trijp, 1991).

Marsh, Balla, and McDonald (1988) proposed that the criteria for ideal fit indices are: 1) relative independence of sample size; 2) accuracy and consistency to assess different models; and 3) ease of interpretation aided by a well-defined continuum or pre-set range. Based on stated criteria, Garver and Mentzer (1999) recommended the Tucker-Lewis index (TLI), the comparative fit index (CFI), and the root mean squared approximation of error (RMSEA), which are all relatively independent of sample size effects. TLI and CFI ranges from 0 to 1 , with values .90 or greater representing an acceptable fit, while RMSEA with values falling between .05 to .08 deemed acceptable (Garver \& Mentzer, 1999). Beside those index, goodness fit idex (GFI), root mean square residual (RMR), normed fit index (NFI) and adjusted goodness of fit index (AGFI) are used to assess overall measurement model fit (Bentler \& Bonett, 1980).

As depicted in Table 1, CFA results, providing an acceptable fit for 5 factor-28 items, demonstrate an acceptable overall measurement model fit. However, for construct 
unidimensionality, second criteria indicating that an acceptable measurement of unidimensional constructs should reveal relatively small standardized residuals and modification indices (Anderson \& Gerbing, 1988), is not supported. High values at modification index and residual covariance table directed the researcher to improve the model by eliminating some items that have higher residual and error term covariance. Thus, 2 items of centralization, 1 items of procedural justice and 2 item of interactional justice construct were deleted because they have higher residuals exceeding 2.58, which is cutoff score commonly accepted (Anderson \& Gerbing, 1988). After elimination of 5 items, remaining 23 items loading 5 factor (Table 2) provided a better model fit (Table 1), which demonstrates construct unidimensionality.

Table 1

CFA Results for Overall Measurement Model Fit

\begin{tabular}{lllll}
\hline & 6 Factor with 28 Items & 6 Factor with 23 Item & Acceptable Fit Index & Better Fit Index \\
\hline GMIN/DF & 2,779 & 2,268 & $\leq 4-5$ & $\leq 3$ \\
GFI & .829 & .892 & $.85-.89$ & $\geq .90$ \\
AGFI & .795 & .864 & $.85-.89$ & $\geq .90$ \\
NFI & .852 & .899 & $.90-.94$ & $\geq .95$ \\
IFI & .900 & .941 & $.90-.94$ & $\geq .95$ \\
CFI & .899 & .940 & $\geq .95$ & $\geq .97$ \\
TLI & .888 & .931 & $.90-.94$ & $\geq .95$ \\
RMR & .061 & .047 & $.06-.08$ & $\leq .05$ \\
RMSEA & .071 & .060 & $.06-.08$ & $\leq .05$ \\
\hline
\end{tabular}

Traditionally, Cronbach's Alpha coefficient has been used to test reliability. Cronbach's alpha ranging from .746 to .897 for each items indicates high item reliability. Besides Cronbach's $\alpha$, composite reliability measure (Werts, Linn, \& Joreskog, 1974) has also been suggested as alternatives to assess construct reliability. Reliable constructs are expected to CR scores above .70. Cronbach's $\alpha$ coefficients and composite reliability (CR) scores exceeding .75 for each constructs (Table 2 ) imply a good construct reliability of all constructs.

After unidimensionality and scale reliability are deemed acceptable, researchers tested convergent validity of constructs as part of construct validation process. Based on Dunn, Seaker, and Waller (1994)'s statement, "If the factor loadings are statistically significant, then convergent validity exists". The researcher assessed statistical significance of the estimated parameters between latent variables and their indicators for convergent validity. Statistically significant factor loadings $(\mathrm{p} \leq .001)$ demonstrate presence of convergent validity (Estimates of regression weights are given in Appendix). Moreover, better fit indices of overall measurement model depicted at Table 1, can be considered as another proof for convergent validity (Garver \& Mentzer, 1999).

For discriminant validity, researcher should verify that scales developed to measure different constructs are indeed measuring different constructs (Garver \& Mentzer, 1999). In other words, discriminant validity indicates that constructs should differ from each other distinctly and independently (Bagozzi, Yi, \& Philips, 1991). As Fornell and Larcker (1981) stated, AVE values exceeding .50 demonstrate discriminant validity of constructs. AVE values 
ranging from .514 to .693 for each constructs indicates discriminant validity of constructs stated on Table 2. Moreover, all 23 items loaded to their estimated constructs with statistically significant factor loadings indicate also discriminant validity of constructs.

Table 2

Items with Factor Loadings and Constructs with CR, Cronbach's $\alpha$ and AVE Values

\begin{tabular}{|c|c|c|c|c|c|}
\hline & 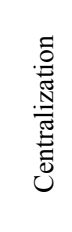 & 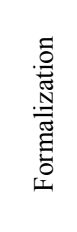 & 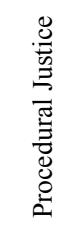 & 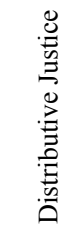 & 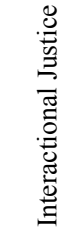 \\
\hline A person who wants to make his own decision would be quickly discouraged here & .525 & & & & \\
\hline Even small matters have to be referred to someone higher up for a final answer & .755 & & & & \\
\hline Employees ask their managers before they do almost anything & .851 & & & & \\
\hline Formalized channels of communication are used for routine processes and practices & & .569 & & & \\
\hline Our standard operating procedures helps us deal with routine problems & & .766 & & & \\
\hline *Employees are 'on their own', even with routine tasks. [R] & & .795 & & & \\
\hline Express my views and feelings during those procedures & & & .591 & & \\
\hline Procedures have been applied consistently & & & .748 & & \\
\hline Procedures have been free of bias & & & .709 & & \\
\hline Procedures have been based on accurate information & & & .793 & & \\
\hline I have been able to appeal the (outcome) arrived at by those procedures & & & .685 & & \\
\hline Procedures upheld ethical and moral standards & & & .766 & & \\
\hline Outcomes reflect the effort I have put into my work & & & & .756 & \\
\hline Outcomes appropriate for the work I have completed & & & & .843 & \\
\hline Outcomes reflect what I have contributed to the organization & & & & .924 & \\
\hline Outcome is justified, given my performance & & & & .797 & \\
\hline Executive has treated me in a polite manner & & & & & .816 \\
\hline Executive has treated me with dignity & & & & & .759 \\
\hline Executive has treated me with respect & & & & & .09 \\
\hline Executive has refrained from improper remarks or comments & & & & & .517 \\
\hline Executive has been candid in (his/her) communications with me & & & & & .896 \\
\hline Executive has explained the procedures thoroughly & & & & & .801 \\
\hline Executive has seemed to tailor (his/her) communications to individuals' specific needs & & & & & .766 \\
\hline Composite Reliability (CR) & .760 & .757 & .864 & .900 & .911 \\
\hline Cronbach Alpha ( $\alpha$ ) & .746 & .748 & .861 & .897 & .897 \\
\hline Average Variance Extracted (AVE) & .523 & .514 & .516 & .693 & .599 \\
\hline
\end{tabular}

* Before analyses are conducted, reverse coded item was corrected by subtracting old values from 6 .

\section{Analyses and Results}

To test hypotheses, the researcher employed Structural Equation Modelling (SEM) with maximum likelihood estimation. Model incorporates two exogenous construct -formalization and centralization, and three endogenous constructs-procedural justices, distributive justice and interactional justice. Although three organizational justice constructs are correlated in theory, SEM using AMOS does not allow to draw covariances among those constructs which are included in to the model as endogenous constructs. When those constructs are treated as unrelated and independent constructs, the first structural regression model provided a good fit to the data. However, when the researcher checked the modification index, she recognized higher covariances between error terms of 2 formalization items (F2 and F3). Based on Cole, Ciesla, and Steiger's (2007) justification in their study, the researcher draws covariance 
between those residuals. After those 2 residuals are connected to each other through covariance, overall model provided a better fit. Table 3 summarizes structural model results for the model depicted in Figure 1.

Table 3

Structural Model Results-Model Fit Indices

\begin{tabular}{|c|c|c|c|c|c|c|}
\hline & \multicolumn{3}{|l|}{ First model } & \multicolumn{3}{|c|}{$\begin{array}{l}\text { Second Model (with residual } \\
\text { covariance) }\end{array}$} \\
\hline GMIN/DF & \multicolumn{3}{|l|}{2.720} & \multicolumn{3}{|c|}{2.306} \\
\hline GFI & \multicolumn{3}{|l|}{.868} & \multicolumn{3}{|l|}{.890} \\
\hline AGFI & \multicolumn{3}{|l|}{.838} & \multicolumn{3}{|l|}{.864} \\
\hline NFI & \multicolumn{3}{|l|}{.876} & \multicolumn{3}{|l|}{.896} \\
\hline IFI & \multicolumn{3}{|l|}{.918} & \multicolumn{3}{|l|}{.938} \\
\hline CFI & \multicolumn{3}{|l|}{.917} & \multicolumn{3}{|l|}{.938} \\
\hline TLI & \multicolumn{3}{|l|}{.907} & \multicolumn{3}{|l|}{.929} \\
\hline RMR & \multicolumn{3}{|l|}{.057} & \multicolumn{3}{|l|}{.051} \\
\hline RMSEA & \multicolumn{3}{|l|}{.070} & \multicolumn{3}{|l|}{.061} \\
\hline \multicolumn{7}{|c|}{ Standardized SEM Estimates-t values and Sig. } \\
\hline & \multicolumn{3}{|c|}{ First model } & \multicolumn{3}{|c|}{$\begin{array}{l}\text { Second Model (with residual } \\
\text { covariance) }\end{array}$} \\
\hline & 声总 & $+\frac{\mathscr{g}}{\frac{\pi}{7}}$ & $\dot{b 0}$ & 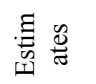 & $\mapsto \stackrel{\frac{0}{\pi}}{\frac{\mathscr{\pi}}{\supset}}$ & $\stackrel{0 D}{\tilde{B}}$ \\
\hline Centralization $>$ Procedural Justice & -.014 & -.300 & .764 & -.027 & -.532 & .595 \\
\hline Centralization $>$ Distributive Justice & -.014 & -.288 & .773 & -.020 & -.372 & .710 \\
\hline Centralization $>$ Interactional Justice & .068 & 1.401 & .160 & .064 & 1.249 & .212 \\
\hline Formalization $>$ Procedural Justice & .921 & 8.923 & $* * *$ & .944 & 8.583 & $* * *$ \\
\hline Formalization $>$ Distributive Justice & .782 & 9.926 & $* * *$ & .790 & 9.281 & $* * *$ \\
\hline Formalization $>$ Interactional Justice & .839 & 10.414 & $* * *$ & .854 & 8.583 & $* * *$ \\
\hline $\mathrm{R}^{2}$ - Procedural Justice & & .848 & & & .891 & \\
\hline $\mathrm{R}^{2}$ - Distributive Justice & & .612 & & & .624 & \\
\hline $\mathrm{R}^{2}$ - Interactional Justice & & .708 & & & .733 & \\
\hline
\end{tabular}

$\mathrm{H}_{1}$ deals with the relationship between centralization and organizational justice. According to analysis results, the effects of centralization on three organizational justice constructsprocedural $(-.027, p>.10)$, distributive $(-.020, p>.10)$ and interactional $(.064, p>.10)$ are not statistically significant. Thus, none of the hypotheses $\left(\mathrm{H}_{1 \mathrm{a}}, \mathrm{H}_{1 \mathrm{~b}}, \mathrm{H}_{1 \mathrm{c}}\right)$ proposing negative relations between centralization and organizational justice constructs was supported.

$\mathrm{H}_{2}$ indicating a positive effect of formalization on organizational justice is totally supported. In other words, all predicted path coefficients were statistically significant, and three hypotheses proposing positive relationship between formalization and organizational justice constructs were supported. Consistent with $\mathrm{H}_{2}$, firms' formalization has positive effect on procedural justice $\left(\mathrm{H}_{2 \mathrm{a}} .944, p<.001\right)$, distributive justice $\left(\mathrm{H}_{2 \mathrm{~b}}: .790, p<.001\right)$ and interactional justice $\left(\mathrm{H}_{2 \mathrm{c}}: .854, p<.001\right)$. Survey findings shaped the research model as depicted in Figure 2. 


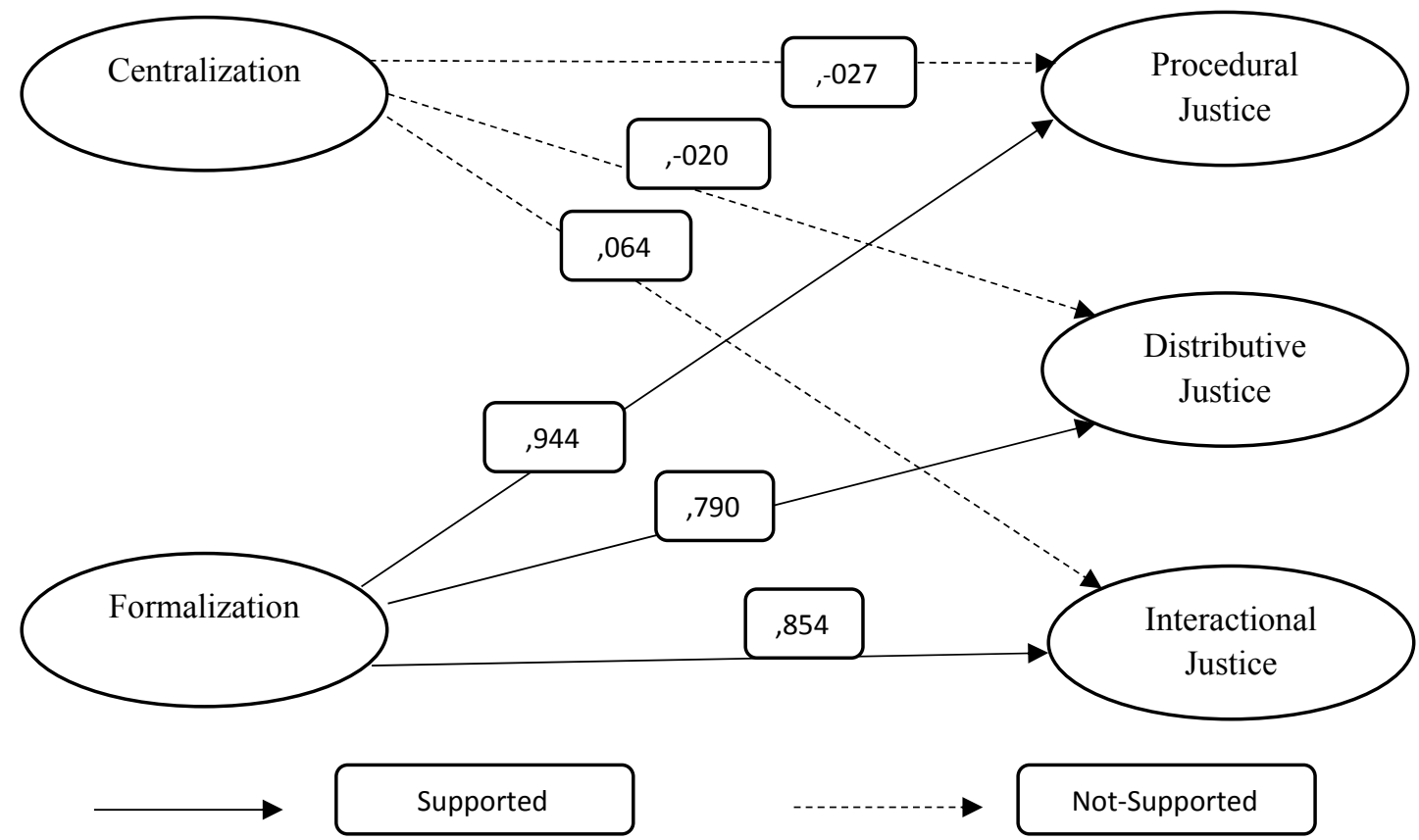

Figure 2. Research model results

\section{Conclusion and Discussion}

In general, this survey found that organizational structure factors have a considerable role in explanations for perceived organizational justice of employees. Specifically, this survey revealed that formalization level as a component of organizational structure affected perceived organizational justice of employees in a positive way. As mentioned previously, in highly formalized organizations, everyone is subject to the same rules and is treated equally under the same circumstances result in employees to perceive their organizations more fair (Leventhal, 1980). Formalized organizations have apparent rules and regulations describing who will do what and how. When people believe that those rules and regulations don't change according to person or time, they strongly trust in justice. Our survey results also support this argument.

Although the findings of this research -indicating positive relationship between formalization level and perceived organizational justice- conflict with Schminke et al.'s (2000) previous research, those findings are consistent with their subsequent research (Schminke et al., 2002) and other surveys in literature (e.g., Altıntaş, 2007). Schminke et al. (2000) found neither linear nor nonlinear effect of formalization on procedural justice in their previous study. They noted that the accuracy of the procedures and rules outweighs the presence or number of procedures and rules. In the other words, only the presence of a number of procedures and rules in an organization may have no meaning in terms of procedural justice perceptions of employees. The accuracy of those rules and the performing of rules accurately should be considered.

However, in their subsequent research, Schminke et al. (2002) found the significant effect of formalization on three types of organizational justice, which is parallel to the findings of the present research. The main difference of their research was the inclusion of hierarchical level 
of respondents as moderator variable. Therefore, the positive effect of organizational structure on organizational justice was more substantial for low-level employees.

A survey, conducted on 86 executives and owners of SMEs operating in Turkey, provided also consistent result with this survey by indicating a positive relationship formalization level and procedural justice (Altıntaş, 2007). Another study conducted in Turkey by İçerli (2009) also found that formalization affected procedural justice, distributive justice and interactional justice positively, which is also parallel to this survey's findings. Based on those findings of surveys conducted in Turkey, it can be stated that above-mentioned rules and procedures increase the perceived organizational justice of Turkish employees.

The findings of this survey also apparently revealed relatively predominant effect of formalization on procedural justice. This finding supports the Leventhal's (1980) principle of "consistency", which is indicated as characteristic of fair procedures. Accordingly, highly formalized organizations have consistent and coherent practices. In a country where managerial decisions are mostly based on individuals' practices rather than the rules or procedures, such as Turkey, individuals are expected to value formalization as a reaction. Therefore, in such a country, formalization is also expected to shape the fairness perception of individuals.

Hypotheses indicating relationships between centralization and three types of organizational justice were not supported by findings of this survey. This finding is inconsistent with the previous studies' results (Schminke et al., 2000; Schminke et al., 2002) and the primary argument that the participation of employees in decision making process increase the perceived fairness level in organizations (Greenberg \& Baron, 2000; Thibaut \& Walker, 1978; Tyler, 2000). In accordance with these results, it can be argued that concentration of decision making power at top level managers does not affect employees' fairness perception in organizations in general.

Even though current survey's findings, revealing a non-significant relationship between centralization and organizational justice (procedural and distributive justice), are inconsistent with previous researches conducted in different countries, two surveys conducted in Turkey about that issue had produced similar results strikingly. Altıntaş (2007) reported that participation of employees in decision making process as a structural factor (Hage \& Aiken, 1967) did not have any significant effect on procedural justice. İçerli (2009) also stated a nonsignificant effect of authority centralization (Hage \& Aiken,1967) on perceived distributive justice.

Including this survey, all studies conducted in Turkey about the above-mentioned issue reported similar results. While findings of those surveys verify the effect of formalization, they have failed to support the effect of centralization on organizational justice. In contrast to most of the universal studies, finding of a non-significant effect of centralization on procedural and distributive justice but a positive effect on interactional justice may have some Turkish culturespecific implications (Sargut, 1994). The main characteristics of Turkish culture, high level of power distance and uncertainty avoidance (Hofstede, 1980), demonstrate more hierarchical and more power centralized organization structures in which the ideal boss/leader/manager is a father figure. When employees trust in that "father figure" namely boss/leader/manager, they are more likely to think that the boss/leader/manager behaves and treats more fairly, thereby are more prone to perceive high level of justice in organizations. Accordingly, it can be stated that concentration of decision making power in the hands of this "father figure"- 
boss/leader/manager- bring about employees to perceive high level of justice in organization because they trust/believe in the fairness of this "father figure". They are more likely to identify fairness of boss/leader/manger with the organizational fairness. Thus, in that kind of studies examining the relationship between centralization and organizational justice, it would be better to assess employees' perception and opinion about their bosses/leaders/managers as a conditional factor. Accordingly, for further studies, it is suggested that the perception of employees about their bosses/leaders/managers should be included in research to acquire more accurate results on centralization-organizational justice relationship.

\section{References}

Aiken, M., \& Hage, J. (1968). Organizational interdependence and intra-organizational structure. American sociological review, 912-930

Altıntaş, F. Ç. (2007). Örgüt yapısının örgütsel politika ve işlem adaleti üzerine etkisinin yapısal denklem modellemesi yardımiyla analizi [Analysis of organizational structure and organizational justice with the help of structural equation modeling]. Anadolu Ünversitesi Sosyal Bilimler Dergisi, 7(2), 151-168.

Ambrose, M. L., \& Schminke, M. (2003). Organization structure as a moderator of the relationship between procedural justice, interactional justice, perceived organizational support, and supervisory trust. Journal of Applied Psychology, 88(2), 295395.

Anderson, J. C., \& Gerbing, D. W. (1988). Structural equation modeling in practice: A review and recommended two-step approach. Psychological bulletin, 103(3), 411-423.

Andrews, M. C., \& Kacmar, K. M. (2001). Discriminating among organizational politics, justice, and support. Journal of Organizational Behavior, 22, 347-366

Auh, S., \& Menguc, B. (2007). Performance implications of the direct and moderating effects of centralization and formalization on customer orientation. Industrial marketing management, 36(8), 1022-1034.

Bagozzi, R. P., Yi, Y., \& Phillips, L. W. (1991). Assessing construct validity in organizational research. Administrative science quarterly, 421-458.

Baum, J. R., \& Wally, S. (2003). Strategic decision speed and firm performance. Strategic Management Journal, 24(11), $1107-1129$.

Bentler, P. M., \& Bonett, D. G. (1980). Significance tests and goodness of fit in the analysis of covariance structures. Psychological bulletin, 88(3), 588-606.

Bies, R. J., \& Moag, J. F. (1986). Interactional Justice: Communication Criteria of Fairness. In R. J. Lewicki, B. H. Sheppard, \& M. H. Bazerman (Eds.), Research on Negotiations in Organizations (pp. 43-55). Greenwich, CT: JAI Press.

Blau, P. M. (1964). Exchange and power in social life. New York: John Wiley.

Byrne, B. M. (2004). Testing for multigroup invariance using AMOS graphics: A road less traveled. Structural Equation Modeling, 11(2), 272-300.

Childs, J. (1973). Strategies of control and organizational behavior. Administrative Science Quarterly, 18, 1-17.

Cohen-Charash, Y., \& Spector, P. E. (2001). The role of justice in organizations: A meta-analysis. Organizational Behavior and Human Decision Processes, 86, 278-321.

Cole, D. A., Ciesla, J. A., \& Steiger, J. H. (2007). The insidious effects of failing to include design-driven correlated residuals in latent-variable covariance structure analysis. Psychological methods, 12(4), 381-391.

Colquitt, J. A. (2001). On the dimensionality of organizational justice: A construct validation of a measure. Journal of Applied Psychology, 86(3), 386-400.

Cropanzano, R., Prehar, C. A., \& Chen, P. Y. (2002). Using social exchange theory to distinguish procedural from interactional justice. Group and Organization Management, 27(3), 324-352.

Daft. R. L. (2015). Örgüt kuramları ve tasarımını anlamak [To understand organizational theories and design]. Ö.N.T. Özmen (Çev. Edt). Ankara: Nobel Akademik yayıncılık

Davis-Sramek, B., Germain, R., \& Krotov, K. (2015). Examining the process R\&D investment-performance chain in supply chain operations: The effect of centralization. International Journal of Production Economics, 167, 246-256. 
Dunn, S. C., Seaker, R. F., \& Waller, M. A. (1994). Latent variables in business logistics research: scale development and validation. Journal of Business Logistics, 15(2), 145-172.

Folger, R., Cropanzano, R. (1998). Organizational justice and human resource management. USA: Sage Publications Inc.

Fornell, C., \& Larcker, D. F. (1981). Structural equation models with unobservable variables and measurement error: Algebra and statistics. Journal of marketing research, 382-388.

Fox, S., Spector, P. E., \& Miles, D. (2001). Counterproductive work behavior (CWB) in response to job stressors and organizational justice: Some mediator and moderator tests for autonomy and emotions. Journal of Vocational Behavior, 59, $1-19$.

Fredrickson, J. W. (1986). The strategic decision process and organizational structure. Academy of management review, 11(2), 280-297.

Garver, M. S., \& Mentzer, J. T. (1999). Logistics research methods: employing structural equation modeling to test for construct validity. Journal of business logistics, 20(1), 33-.

Greenberg, J. (1987). Reactions to procedural injustice in payment distributions: do the means justify the ends? Journal of Applied Psychology, 72(1), 55-61.

Greenberg, J. (1990). Employee theft as a reaction to underpayment inequity: The hidden cost of pay cuts. Journal of Applied Psychology, 75(5), 561-568.

Greenberg, J. (1993). The social side of fairness: interpersonal and informational classes of organizational justice. In Russell CROPANZANO; Justice in the Workplace: Approaching Fairness in Human Resource Management, Lawrence Erlbaum Associates, Publishers, New Jersey.

Greenberg, J., \& Baron R. A. (2000). Behavior in organizations. New Jersey, USA: Prentice Hall Inc.

Hage, J., \& Aiken, M. (1967). Relationship of centralization to other structural properties. Administrative Science Quarterly, 12, 72-92.

Hofstede, G. (1980). Culture's consequences: International differences in work-related Values, Thousand Oaks, CA: Sage

Ivancevich, J. M., \& Donnelly J, J. H. (1975). Relation of organizational structure to job satisfaction, anxiety-stress, and performance. Administrative science quarterly, 272-280.

İçerli, L. (2009). Örgüt yapısı ve örgütsel adalet arasındaki ilişkiler [Relationship between organizational structure and organizational justice] (Unpublished doctoral dissertation). Dokuz Eylül Üniversitesi Sosyal Bilimler Enstitüsü İşletme Anabilim Dalı Yayınlanmamış Doktora Tezi.

Jaworski, B. J., \& Kohli, A. K. (1993). Market orientation: Antecedents and consequences. The Journal of marketing, 53-70.

Khandwalla, P. (1977). The design of organizations. New York: Harcourt, Brace and Jovanovich.

Lambert, E. G., Paoline III, E. A., \& Hogan, N. L. (2006). The impact of centralization and formalization on correctional staff job satisfaction and organizational commitment: An exploratory study. Criminal Justice Studies, 19(1), 23-44.

Leventhal, G. S. (1980). What should be done with equity theory? In K. J. Gergen, M. S. Greenberg, \& R. H. Willis (Eds.) Social exchange: Advances in theory and research (pp. 27-55). New York: Plenum.

Marsh, H. W., Balla, J. R., \& McDonald, R. P. (1988). Goodness-of-fit indexes in confirmatory factor analysis: The effect of sample size. Psychological bulletin, 103(3), 391-410.

Masterson, S. S., Lewis, K., Goldman, B. M., \& Taylor, M. S. (2000). Integrating justice and social exchange: The differing effects of fair procedures and treatment on work relationships. Academy of Management Journal, 43, 738-748.

Mayer, D., Nishii, L., Schneider, B., \& Goldstein, H. (2007). The precursors and products of justice climates: group leader antecedents and employee attitudinal consequences. Personnel Psychology, 60,929-963.

McFarlin, D. B., \& Sweeney, P. D. (1992). Distributive and procedural justice as predictors of satisfaction with personal and organizational outcomes. Academy of Management Journal, 35(3), 626-638.

Moorman, R. H. (1991). Relationship between organizational justice and organizational citizenship behaviors: do fairness perception influence employee citizenship? Journal of Applied Psychology, 76(6), 845-855.

Oldham, G. R., \& Hackman, J. R. (1981). Relationships between organizational structure and employee reactions: Comparing alternative frameworks. Administrative Science Quarterly, 26(1), 66-83.

Özşahin, M. (2005). Stratejik karar verme hızını etkileyen faktörler ve stratejik karar verme hızı-firma performansı iişkisi [factors affecting strategic decision-making speed and strategic decision-making speed-firm performance relationship] (Unpublished master's thesis). Gebze Institute of Technology, Business Administration, Gebze.

Sargut, A. S. (1994). Bireycilik ve ortaklaşa davranış ikileminde yönetim ve örgüt kuramları [Management and organization theories in the dilemma of individualism and common behavior]. Ankara Üniversitesi SBF Dergisi, 49(01), 321-332. 
Schminke, M., Ambrose, M. L., \& Cropanzano, R. S. (2000). The effect of organizational structure on perceptions of procedural fairness. Journal of Applied Psychology, 85(2), 294-304.

Schminke, M., Cropanzano, R., \& Rupp, D. E. (2002). Organization structure and fairness perceptions: The moderating effects of organizational level. Organizational Behavior and Human Decision Processes, 89(1), 881-905.

Steenkamp, J. B. E., \& Van Trijp, H. C. (1991). The use of LISREL in validating marketing constructs. International Journal of Research in marketing, 8(4), 283-299.

Thibaut, J., \& Walker, L. (1978). A theory of procedure. California Law Review, 66(3), 541-566.

Tyler, T. R. (2000). Social justice: Outcome and procedure. International Journal of Psychology, 35(2), 117-125.

Yang, Z., Zhou, X., \& Zhang, P. (2015). Centralization and innovation performance in an emerging economy: testing the moderating effects. Asia Pacific Journal of Management, 32(2), 415-442.

Yürür, S. (2015). Türkiye'de örgütsel adalet konusunda yapılan çalışmalara ilişkin bir derleme [Compilation of a study carried out in turkey regarding organizational justice]. In R. Ö. Kutanis (Ed.), Türkiye'de örgütsel davranış çalışmaları-I. Gazi Kitabevi, Ankara.

Yürür, S., \& Demir, K. (2011). örgütsel adalet ve psikolojik güçlendirme karş1lıklı etkileri üzerine bir araștırma [A research on the mutual effects of organizational justice and psychological empowerment]. Süleyman Demirel Üniversitesi İktisadi ve İdari Bilimler Fakültesi Dergisi, 16(3), 311-335.

Werts, C. E., Linn, R. L., \& Jöreskog, K. G. (1974). Quantifying unmeasured variables. Measurement in the social sciences. In H. M. Blalock (Ed.), Measurement in social sciences: Theories and strategies (pp. 270-292). Chicago: Aldine. 